\title{
EFFECTS OF REDUCING POSTPARTUM RE-MATING TIME- PERIOD ON REPRODUCTIVE PERFORMANCE OF THE DOE
}

\author{
RÉDUCTION POST PARTURITION RE-ACCOUPLEMENT PÉRIODE LA \\ PERFORMANCE DE LA REPRODUCTION DU LAPINE
}

\begin{abstract}
Awojobi, H.A. ${ }^{1 *}$, Awojobi, E.A. ${ }^{1}$, Adejumo, D.O. ${ }^{2}$, Eniolorunda, O.O. ${ }^{1}$ and Aluko, F.A. ${ }^{1}$
${ }^{1}$ Department of Animal Production and College of Agricultural Sciences. Olabisi Onabanjo University. Yewa Campus. Ayetoro. Ogun State. Nigeria.

${ }^{2}$ Department of Animal Science. University of Ibadan. Ibadan. Nigeria. hezeking@gmail.com
\end{abstract}

\section{AdDitional KEYWORDS}

Tropics.

\section{SUMMARY}

Rabbits being induced ovulators can be rebred within 24 hours after parturition. However, reproductive efficiency and the doe's physiology can be affected by postpartum re-mating interval. This study evaluated the effects of reducing the re-mating interval after parturition on sexual activity, fertility, gestation, parturition and litter characteristics using 90 does. Three groups of crossbred (New Zealand White $\times$ Chinchilla) does were used in a randomized complete block design. Does were re-mated 1-9, 10-20 and 21-28 days after parturition in the dry and rainy seasons in Ayetoro, Ogun State, Nigeria. Acceptance of mating decreased with increasing postpartum remating interval. Conception rate was highest in the 21-28 days group (98.8\%) and lowest in the 1020 days group (68.4\%). Gestation length was significantly shorter $(p<0.05)$ in the $10-20$ days group (30.7 days), than 1-9 days group (31.6 days) and 21-28 days group (31.7 days). Litter size and weight at birth were not significantly affected. Kit's mortality was lower $(p<0.05)$ in the $21-28$ days group (25.6\%) compared to $10-20$ days group (57.4\%) and 1-9 days group (58.8\%). Litter weight (total and alive at birth) was heavier $(p<0.05)$ during the rains $(295.9$ and $294.9 \mathrm{~g}$ ) than dry season (250.1 and $243.3 \mathrm{~g}$ ). Reducing the re-mating interval after parturition enhanced sexual activity. Fertility

\section{Mots ClÉs ADITIONNELLES}

Zone tropicale.

was comparable in does re-mated 1-9 and 21-28 days after parturition.

\section{RÉSUMÉ}

Les lapins étant des ovulateurs incités peuvent reprocréer en moins de 24 heures après la parturition. Cependant l'intervalle de récopulation postpartum peut influer sur el efficacité de reproduction et sur la physiologie de la lapine. Cette étude a évalué les effets de la réduction de l'intervalle de ré-accouplement après la naissance sur l'activité sexuelle, la fertilité, la gestation, la parturition et les caractéristiques des petits, en utilisant 90 lapines. Trois groupes de lapines de race croisée (New Zealand White $\times$ Chinchilla) ont été utilisés dans un bâtiment découpé en cabines de dimensions prises au hazard. Les lapines ont été ré-accouplées entre 1 à 9,10 à 20,21 à 28 jours après la parturition les saisons sèches et pluvieuse à Ayetoro, dans e' Etat d'Ogun au Nigeria. L'acceptation de récopulation a décru avec l'accroissement de l'intervalle de récopulation postpartum. Le taux de conception était le plus élevé dans le groupe de 21 à 28 jours $(98,8 \%)$ et le plus bas dans le groupe de 10 à 20 jours $(68,4 \%)$. La durée de gestation était considérablement plus courte $(p<0,05)$ dans le groupe de 10 à 20 jours (30,7 jours) que dans le groupe 
de 1 à 9 jours (31,6 jours) et que dans le groupe de 21 à 28 jours (31,7 jours). La grosseur et le poids des petits à la naissance n'étaient pas pour autant affectés. La mortalité à la naissance était plus basse $(p<0,05)$ dans le groupe de 21 à 28 jours (25,6\%) par rapport aux groupes de 10 à 20 jours $(57,4 \%)$ et de 1 à 9 jours $(58,8 \%)$. Le poids des petits (total et vivants à la naissance) était plus lourd $(p<0,05)$ pendant les pluies $(295,9$ et $294,9 \mathrm{~g})$ que pendant la sécheresse $(250,1 \mathrm{et}$ $243,3 \mathrm{~g}$ ). La réduction de l'intervalle de récopulation après parturition a augmenté l'activité sexuelle. La fertilité était comparable chez les lapines ré accouplées dans les groupes de 1 à 9 et de 21 à 28 jours après parturition.

\section{INTRODUCTION}

The advantage of raising rabbits for human consumption rests on their potential biological efficiency. However, the gap between biological potential and practical achievement is still wide in terms of reproductive performance. The situation appears evidently more precarious in developing countries. According to Cheeke (1986), rabbits are induced ovulators and will breed within 24 hours of parturition. Thus, it is theoretically possible to produce over 11 litters per doe per year. This author further stated that this intensive type of production could not be obtained in developing countries, but it is quite feasible to produce 3 to 5 litters per year.

Apart from inadequate market for products, another limitation to rabbit production in the tropics is inadequate skill on the part of farmers for rabbit management, particularly reproduction management. An important factor is dearth of information as reported by Awojobi et al. (2005). In Europe the introduction of cycled production and artificial insemination (AI) has improved management and productivity of the doe. However, cyclic production is giving way to the development of different reproduction protocols since continuous postpartum rhythm decreases fertility rate and length of reproductive activity (Parigi-Bini et al., 1989) and only a few does can sustain a fixed postpartum rhythm (Castellini et al., 2003). Another obvious consideration for this development is the question of animal welfare.

In the tropics there is dearth of information on the physiology of the domestic rabbit after parturition. A proper understanding of postpartum reproductive physiology in the domestic rabbit within the confines of the limitations of the tropical environment will assist in establishing the most effective ways of managing rabbit reproduction for optimal performance. It will also enable an avenue for mapping out strategy for improving reproductive performance. Though, commercial rabbit production is still in its infancy in most developing countries, Nigeria inclusive, therefore the availability of correct information on reproduction management is one of the catalysts needed for the development of the rabbit industry.

\section{MATERIALSAND METHODS}

\section{EXPERIMENTALFARM AND CLIMATE}

This research was carried out at the rabbitry of the Teaching and Research Farm, College of Agricultural Sciences, Olabisi Onabanjo University, Yewa Campus, Ayetoro, Ogun State, Nigeria.

Ayetoro is located in latitude $7^{\circ} 15^{\prime} \mathrm{N}$ and longitude $3^{\circ} 3^{\prime} \mathrm{E}$ in a deciduous/derived savannah zone of Ogun State. Climate is sub-humid tropical with an annual rainfall of $1909.3 \mathrm{~mm}$. Rainy season is between early April and late October. Rainfall pattern is bimodial with two peaks in June and September. Maximum temperature varies between $29^{\circ} \mathrm{C}$ during the peak of the wet season and $34^{\circ} \mathrm{C}$ at the onset of the wet season. Mean annual relative humidity is 81\% (Onakomaiya et al., 1992).

\section{ANimals AND PRE-EXPERIMENTAL MANAGEMENT}

One hundred and twenty does were 
prepared for this experiment. The does were a cross of New Zealand White does and Chinchilla bucks. 60 does were born between march and april 2004 and the remaining 60 between october and november 2004 to be used for the experiment during the following dry and rainy seasons respectively. The does were weaned at 28 days of age and housed in collective cages (four young rabbits per cage) up to 12 weeks of age.

At 12 weeks of age they were reduced to two per cage until 18 weeks of age when they were individually caged. From weaning to 12 weeks of age they were fed a concentrate ration containing: $16 \% \mathrm{CP}, 2500$ kcal DE/kg, 7.5\% CF, 3.5\% EE ad libitum. Thereafter, they were fed a diet containing $15 \%$ CP, $2400 \mathrm{kcal}$ DE/kg, 8.15\% CF, 3.17\% EE until 20 weeks of age. Beginning from 12 weeks of age feed was restricted to $100 \mathrm{~g} /$ animal/day. The amount was then increased by $10 \mathrm{~g}$ biweekly up to $150 \mathrm{~g}$ until they were ready for breeding at 22 weeks of age.

The young does were given prophylactic doses of pluricoccin $(5 \mathrm{mg} / \mathrm{kg}$ body weight) and ivomec $(0.1 \mathrm{mg} / \mathrm{kg}$ body weight) against coccidiosis and ecto/ endoparasites respectively at 12 and 20 weeks of age.

\section{ANIMALSAND EXPERIMENTAL GROUPS}

A total of ninety nulliparous does, 22 weeks old equalized for the average initial live weights was used. Forty-five does each during the dry and rainy seasons were allocated to one of three groups, each group having fifteen replicates of one doe per replicate in a randomised complete block design. The grouping was based on three postpartum re-mating time periods, which became effective after the first parturition. The groups are: intensive (1-9 days postpartum re-mating), semi-intensive (10-20 days postpartum re-mating), and extensive (21-28 days postpartum re-mating).

\section{HOUSING ANDENVIRONMENT}

Animals were individually caged in cells measuring $0.9 \times 0.6 \times 0.45 \mathrm{~m}$. Cages are made of wooden frames with wire netting on the sides and the base in a flat-deck system. Feed and water are provided in earthen pots secured to prevent spillage. Cages are kept indoors in a closed building roofed with asbestos sheet and equipped with windows for cross ventilation. The housing uses natural ventilation with no thermal insulation or cooling system. Does were kept under natural lighting throughout the experiment.

\section{FEEDINGANDNUTRITION}

Does were given unrestricted access to water supply and concentrate containing $18 \%$ CP, 9\% CF, $2500 \mathrm{kcal}$ DE/kg, 3.85\% EE from 22 weeks of age to the first kindling. Following the first kindling does was subjected to the three postpartum re-mating systems described earlier. From the first kindling to the end of the trial does were fed another concentrate ration (table I). Feed and water were supplied ad libitum throughout.

\section{BREEDING SYSTEM}

Mating was done in the morning using nine tested adult bucks in each season (mating ratio of 1 buck to 5 does). A doe is presented for mating two to three times in 15 to 30 minutes using two or three bucks. Presentation for mating was done every other day in case of refusal to mate.

\section{RECORDEDPERFORMANCES}

The following data were recorded/ computed during the experiment:

- Mating behaviour: The number of does that accepted the buck for mating within their respective treatment group was recorded. Number of presentations before acceptance and the number of matings per conception were also recorded.

- Conception rate: The number of does that accepted mating that tested positive to pregnancy diagnosis by abdominal palpation on the $12^{\text {th }}$ day after mating relative to the number that mated expressed 
as a percentage.

- Pregnancy rate: The number of does that kindled relative to number of does mated expressed as a percentage.

- Kindling rate: The number of does that kindled relative to the number of does in each experimental grouping expressed as a percentage.

- Gestation length: The number of days from mating to kindling.

- Litter size: These comprise litter size (total and alive) at birth and weekly litter size until weaning at four weeks of age. Litters were not standardized after birth.

- Re-mating interval: The actual number of days after parturition when the doe remated.

- Parturition interval: The number of days between parturitions.

- Survival index: Calculated as described by Fraga et al. (1989) as No. of pups per litter at 21 days/No born alive per litter.

- Mortality: Kit mortality was recorded on a weekly basis across treatment and season.

The proximate analysis of the diet used during the experiment was carried out using the method of A.O.A.C. (1995).

\section{StATISTICAL ANALYSIS}

Measurements were analyzed with remating interval and season as factors of variation. All data collected were subjected to analysis of variance using the GLM procedure of SAS (1999), employing the model:

$$
Y i j k=\mu+M i+S j+(M S) i j+E i j k
$$

where:

Yij= individual observation;

$\mu=$ general population mean;

$\mathrm{Mi}=$ effect of mating system $\mathrm{i}$;

$\mathrm{Sj}=$ effect of season $\mathrm{j}$;

(MS)ij= effect of Interaction between mating;

system i and season j;

Eijk= composite error effect.

Significant means were separated using
Table I. Composition of experimental diet. (Composition du régime expérimental).

\begin{tabular}{lr}
\hline Ingredient & Quantity(\%) \\
\hline Maize & 32.40 \\
Soya bean meal & 23.10 \\
Wheat meal & 9.30 \\
Palm kernel cake & 13.90 \\
Brewers dried grain & 13.90 \\
Fish meal (72\%) & 1.86 \\
Palm oil & 1.80 \\
Oyster shall & 1.40 \\
Bone meal & 1.85 \\
Premix & 0.20 \\
Salt & 0.30 \\
Analysis & \\
Dry matter (\%) & 91.50 \\
Energy (Kcal ME/kg) & 2666.88 \\
Crude protein (\%) & 23.80 \\
Ether extract (\%) & 6.45 \\
Crude fibre (\%) & 10.84 \\
\end{tabular}

Premix supplied the following per $\mathrm{kg}$ of feed: $\mathrm{Vit} A=$ 10100 i.u ; Vit $D=32000$ i.u; Vit $E=30$ mg; Vit $K=$ $3.2 \mathrm{mg}$; Vit B1= $100 \mathrm{mg}$; Vit $B=2,400 \mathrm{mg}$; Nicotinic acid $=25 \mathrm{mg} ;$ Panthothenic acid $=8 \mathrm{mg}$; Vit B6 $=3$ $\mathrm{mg}$; Vit B12 $=0.015 \mathrm{mg}$; Folic acid $=0.80 \mathrm{mg}$; Biotin= $0.030 \mathrm{mg}$; Choline chloride $=200 \mathrm{mg}$; Manganese $=$ $100 \mathrm{mg}$, Iron= $50 \mathrm{mg}$; Zinc $=45 \mathrm{mg}$; Copper $=2 \mathrm{mg}$; lodine $=1.55 \mathrm{mg}$; Cobalt $=0.25 \mathrm{mg}$; Selenium $=0.10$ $\mathrm{mg}$; Ethoxyquin $=100 \mathrm{mg}$.

the Duncan option of the same package.

\section{RESULTS}

The effect of postpartum re-mating interval on acceptance of male is summarized in table II. The acceptance of the male for mating decreased as postpartum re-mating interval increased. Number of presentations before mating in does that accepted mating was significantly $(\mathrm{p}<0.05)$ higher for does under semi-intensive and extensive remating than does under intensive system (table II).

Average conception rate measured by abdominal palpation at day 12 post coitum was $76.9 \%, 68.4 \%$ and $98.8 \%$ for does under

Archivos de zootecnia vol. 60, núm. 231, p. 504. 
Table II. Effects of experimental post partum re-mating interval on mating acceptance in the doe rabbit. (Effets de l'intervalle expérimental de ré-accouplement postpartum sur l'acceptation de copulation chez la lapine).

\begin{tabular}{lcccr}
\hline & $\begin{array}{c}\text { Re-mating interval } \\
\text { Intensive } \\
1-9 \text { days }\end{array}$ & $\begin{array}{c}\text { Semi-intensive } \\
10-20 \text { days }\end{array}$ & $\begin{array}{c}\text { Extensive } \\
21-28 \text { days }\end{array}$ & SEM \\
\hline Re-mating interval (days) & $1.96^{\mathrm{c}}$ & $13.89^{\mathrm{b}}$ & $24.19^{\mathrm{a}}$ & 1.78 \\
Mating acceptance (\%) & $86.7^{\mathrm{a}}$ & $63.3^{\mathrm{b}}$ & $53.3^{\mathrm{b}}$ & 5.23 \\
No of presentations & $1.31^{\mathrm{b}}$ & $2.50^{\mathrm{a}}$ & $2.30^{\mathrm{a}}$ & 0.71 \\
No of matings at acceptance & 2.30 & 1.70 & 1.80 & 0.60 \\
\hline
\end{tabular}

${ }^{a b c}$ Means on the same row bearing different superscripts are significantly $(p<0.05)$ different.

SEM: Standard error of mean.

the intensive, semi-intensive and extensive re-mating systems respectively. Though acceptance of the male for mating was lowest in does under extensive mating system (table II), conception rate was highest in their group. Even when litter size at mating was $>5$, does in this group still demonstrated a high conception rate. Pregnancy rate was intensive (57.69\%), semi-intensive (52.63\%) and extensive (93.75\%). On the whole kindling rate was $50 \%, 33.3 \%$ and $50 \%$ for does under the intensive, semi-intensive and extensive mating systems respectively (table III). Invariably, kindling rate was comparable between does on intensive and extensive mating systems.

Main effects of experimental postpartum re-mating interval and season on gestation length are shown in table III. Gestation length was significantly $(\mathrm{p}<0.05)$ lower in

Table III. Effects of postpartum re-mating interval and season on reproductive performance of the doe rabbit. (Effets de l'intervalle et de la saison du ré accouplement postpartum sur la performance reproductive chez la lapine).

\begin{tabular}{|c|c|c|c|c|c|c|c|}
\hline & $\begin{array}{c}\text { Intensive } \\
1-9 \\
\text { days }\end{array}$ & $\begin{array}{c}\text { Re-mating inter } \\
\text { Semi-intensive } \\
10-20 \\
\text { days }\end{array}$ & $\begin{array}{l}\text { rval } \\
\text { Extensive } \\
21-28 \\
\text { days }\end{array}$ & SEM & $\begin{array}{l}\text { Seasc } \\
\text { Dry }\end{array}$ & Rain & SEM \\
\hline Gestation length (days) & $31.60^{\mathrm{a}}$ & $30.70^{\mathrm{b}}$ & $31.60^{\mathrm{a}}$ & 0.30 & 31.52 & 31.21 & 0.24 \\
\hline Remating interval (days) & $1.93^{c}$ & $14.20^{\mathrm{b}}$ & $25.87^{\mathrm{a}}$ & 0.63 & $11.71^{\mathrm{b}}$ & $16.47^{\mathrm{a}}$ & 0.50 \\
\hline Parturition interval (days) & $33.53^{c}$ & $44.90^{\mathrm{b}}$ & $57.53^{\mathrm{a}}$ & 0.73 & 43.24 & 47.74 & 0.57 \\
\hline Litter size (total) & 5.80 & 5.60 & 5.13 & 0.46 & 5.29 & 5.74 & 0.36 \\
\hline Litter size (alive) & 5.60 & 5.50 & 5.13 & 0.49 & 5.19 & 5.63 & 0.39 \\
\hline Litter weight (g) (total) & 283.57 & 252.50 & 274.33 & 19.60 & $250.12^{b}$ & $296.89^{a}$ & 15.49 \\
\hline Litter weight (g) (alive) at birth & 271.57 & 250.00 & 274.33 & 21.01 & $243.33^{b}$ & $294.92^{\mathrm{a}}$ & 16.61 \\
\hline Kindling rate (\%) & 50.00 & 33.33 & 50.00 & - & 46.67 & 42.22 & - \\
\hline No of observations & 15 & 10 & 15 & - & 21 & 19 & - \\
\hline
\end{tabular}

${ }^{a b c}$ Means on the same row bearing different superscripts are significantly $(p<0.05)$ different. SEM: Standard error of mean. 
Table IV. Interaction effects of postpartum re-mating interval $x$ season on reproductive performance of the doe. (Effets d'interaction de l'intervalle et de la saison de récopulation postpartum sur la performance reproductive de la lapine).

\begin{tabular}{|c|c|c|c|c|c|c|c|}
\hline & \multicolumn{2}{|c|}{$\begin{array}{l}\text { Intensive } \\
1-9 \text { days }\end{array}$} & $\begin{array}{r}\text { Re-matir } \\
\text { Semi-ir } \\
10-20\end{array}$ & $\begin{array}{l}\text { g interval } \\
\text { tensive } \\
\text { days }\end{array}$ & $\begin{array}{r}\text { Exte } \\
21-2 \varepsilon\end{array}$ & $\begin{array}{l}\text { nsive } \\
\text { days }\end{array}$ & \multirow[t]{2}{*}{ SEM } \\
\hline & Dry & Rain & Dry & Rain & Dry & Rain & \\
\hline Gestation length (days) & 32.00 & $30.83^{b}$ & 30.40 & 31.10 & 31.71 & 31.50 & 0.83 \\
\hline Remating interval (days) & $1.00^{c}$ & $3.33^{c}$ & $13.20^{\mathrm{b}}$ & $15.20^{\mathrm{b}}$ & $24.43^{\mathrm{a}}$ & $27.13^{\mathrm{a}}$ & 1.86 \\
\hline Parturition interval (days) & $33.00^{c}$ & $34.33^{c}$ & $43.60^{b}$ & $46.20^{b}$ & $56.14^{\mathrm{a}}$ & $58.75^{a}$ & 0.99 \\
\hline Litter size (total) & 5.30 & 6.50 & 6.40 & 4.80 & 4.40 & 5.75 & 0.59 \\
\hline Litter size (alive) & 5.10 & 6.33 & 6.40 & 4.60 & 4.40 & 5.75 & 0.60 \\
\hline Litter weight (g) (total) & $243.06^{b}$ & $344.33^{a}$ & $275.00^{a}$ & $230.00^{b}$ & $241.43^{b}$ & $303.13^{a}$ & 27.75 \\
\hline Litter weight (g) (alive) at birth & $227.22^{\mathrm{b}}$ & $338.08^{a}$ & $274.00^{\mathrm{a}}$ & $225.00^{b}$ & $241.43^{b}$ & $303.13^{\mathrm{a}}$ & 28.11 \\
\hline
\end{tabular}

${ }^{a b c}$ Means on the same row with different superscripts are significantly $(p<0.05)$ different.

SEM: Standard error of mean.

does under the semi-intensive mating system (30.70 days) than does on intensive and extensive mating systems. Average gestation length was 31.60 days for does under intensive and 31.68 days for does under extensive mating systems. Gestation length was not significantly $(\mathrm{p}>0.05)$ different between the rainy and dry seasons. No significant ( $p>0.05$ ) re-mating interval $x$ season interaction was observed for gestation length (table IV).

Postpartum re-mating interval was significantly $(\mathrm{p}<0.05)$ different among mating systems (tables II and III). Remating interval was significantly $(\mathrm{p}<0.05)$ longest in does on the extensive system and significantly $(p<0.05)$ shortest in does under the intensive system. Re-mating

Table $\boldsymbol{V}$. Main effects of postpartum re-mating interval and season on litter characteristics of the previous parturition. (Principaux effets de l'intervalle et de la saison de recopulation postpartum sur les caractéristiques des petits de la parturition précédente).

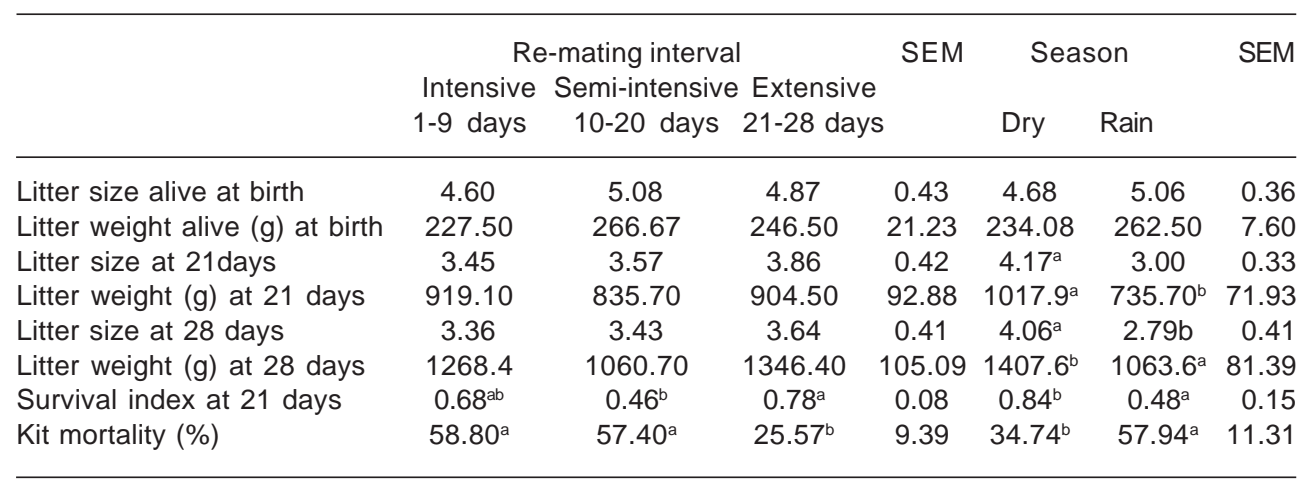

abcMeans on the same row bearing different superscripts are significantly $(p<0.05)$ different.

SEM: Standard error of mean.

Archivos de zootecnia vol. 60, núm. 231, p. 506. 
Table VI. Interaction effects of postpartum re-mating interval x season on litter characteristics of the previous parturition. (Effets d'interaction de l'intervalle et de la saison de re-accouplement postpartum sur les caractéristiques des petits de la parturition précédente).

\begin{tabular}{|c|c|c|c|c|c|c|c|}
\hline & \multicolumn{2}{|c|}{$\begin{array}{l}\text { Intensive } \\
1-9 \text { days }\end{array}$} & \multicolumn{2}{|c|}{$\begin{array}{l}\text { Re-mating interval } \\
\text { Semi-intensive } \\
10-20 \text { days }\end{array}$} & \multicolumn{2}{|c|}{$\begin{array}{l}\text { Extensive } \\
21-28 \text { days }\end{array}$} & \multirow[t]{2}{*}{ SEM } \\
\hline & Dry & Rain & Dry & Rain & Dry & Rain & \\
\hline Litter size alive at birth & 4.7 & 5.6 & 4.8 & 4.4 & 4.6 & 5.1 & 0.72 \\
\hline Litter wt. alive at birth (g) & 235.70 & 310.00 & 240.00 & 215.00 & 228.00 & 262.50 & 35.0 \\
\hline Litter size at 21 days & $4.38^{\mathrm{a}}$ & $2.00^{\mathrm{b}}$ & $4.70^{\mathrm{a}}$ & $2.00^{\mathrm{b}}$ & $3.70^{\mathrm{a}}$ & $3.90^{\mathrm{a}}$ & $0.67^{*}$ \\
\hline Litter wt. (g) at 21 days & $055.43^{\mathrm{a}}$ & $681.25^{\mathrm{b}}$ & $1050.00^{\mathrm{a}}$ & $550.00^{\mathrm{b}}$ & $962.50^{a}$ & $896.88^{\mathrm{a}}$ & $85.35^{\star}$ \\
\hline Litter size at 28 days & $4.10^{\mathrm{a}}$ & $2.0^{\mathrm{b}}$ & $4.50^{\mathrm{a}}$ & $2.0^{\mathrm{b}}$ & $3.70^{\mathrm{a}}$ & $4.00^{\mathrm{a}}$ & $0.57^{*}$ \\
\hline Litter wt. at 28 days (g) & $1491.07^{a}$ & $878.75^{b}$ & $1312.50^{\mathrm{a}}$ & $725.00^{\mathrm{b}}$ & $1378.57^{\mathrm{a}}$ & $1314.29^{a}$ & 87.63 \\
\hline Survival index at 21 days & $0.74^{\mathrm{a}}$ & $0.31^{\mathrm{b}}$ & $0.73^{\mathrm{a}}$ & $0.19^{\mathrm{b}}$ & $0.81^{\mathrm{a}}$ & $0.76^{\mathrm{a}}$ & $0.11^{\star *}$ \\
\hline Kit mortality (\%) (0-28days) & $46.95^{\mathrm{b}}$ & $76.67^{a}$ & $39.21^{b c}$ & $75.48^{\mathrm{a}}$ & $15.71^{\mathrm{c}}$ & $34.20^{\mathrm{bc}}$ & $12.72^{*}$ \\
\hline
\end{tabular}

${ }^{a b c}$ Means on the same row with different superscripts are significantly different; ${ }^{*} p<0.05 ;{ }^{* *} p<0.01$. SEM: Standard error of mean.

interval was shorter $(\mathrm{p}<0.05)$ in the dry season than rainy season (table III). The re-mating interval $x$ season interaction in respect of postpartum re-mating interval is shown in table IV. Re-mating interval was longer ( $p>0.05)$ in all three mating systems during the rainy season than the dry season. Results of the parturition interval followed the same trend as the re-mating interval. Parturition interval was significantly $(p<0.05)$ longer in the rainy season than the dry season (table III). Re-mating interval $x$ season interaction in respect of parturition interval is also shown in table IV. Parturition interval was longer $(p>0.05)$ in the rainy season across all three mating systems.

Results (table III) showed that litter size at birth (total/alive) was not significantly ( $>0.05)$ affected by mating system and season. No significant ( $\mathrm{p}>0.05)$ re-mating interval $\mathrm{x}$ season interaction was equally observed in litter size at birth (table IV). Stillbirth, though decreasing with increasing time to mating after parturition, was equally not influenced by mating system and season.

Litter weight (total and alive) at birth (table III) showed no significant $(\mathrm{p}>0.05)$ differences among the three mating systems. The litter weights were however heavier $(\mathrm{p}<0.05)$ during the rainy season than the dry season. Table IV shows that significant $(\mathrm{p}<0.05)$ re-mating interval $\mathrm{x}$ season interaction existed for litter weight (total and alive). The litter weights were significantly $(\mathrm{p}<0.05)$ lower in the rainy than dry season for does under the semiintensive mating.

The effects of experimental re-mating interval and season on the litter characteristics of the previous parturition are shown in table V. Number of kits born alive and litter weight (alive) at birth were neither ( $>0.05$ ) affected by postpartum re-mating interval nor season. There was no re-mating interval $x$ season interaction ( $p>0.05$ ) in the expression of these two indices (table VI). These two parameters (litter size and litter weight at 21 days) were however significantly $(p<0.05)$ affected by season. Both parameters were higher $(\mathrm{p}<0.05)$ during the dry season than the rainy season. Litter size at 28 days followed exactly the same trend as for 21 days. Litter weight was however highest for does under extensive 
re-mating, followed by intensive and then semi-intensive, albeit values were not significantly ( $>00.05)$ different. Survival index at 21 days was significantly $(\mathrm{p}<0.05)$ higher in does under extensive re-mating than does under semi-intensive re-mating system. Does re-mated under the intensive system however had values comparable ( $>0.05$ ) to that of both the semi-intensive and extensive re-mating systems.

Table VI shows the re-mating interval $x$ season interaction effect for litter characteristics of the previous parturition. They were all comparable ( $p>0.05)$ during the dry season for the three re-mating systems. However, experimental animals re-mated 1-9 days postpartum and 10-20 days postpartum showed significant $(\mathrm{p}>0.05)$ reduction in litter size and weights at 21 days and 28 days postpartum and decreased ( $p>0.05$ ) survivability at 21 days during the rainy season than the dry season. Overall kits mortality from birth to weaning was significantly $(\mathrm{p}<0.05)$ lower in does under the extensive re-mating system when compared to does on the intensive and semi-intensive systems. Kit mortality from birth to weaning was significantly $(\mathrm{p}<0.05)$ affected by season being higher in the rainy season than dry season. Overall kit mortality showed significant $(\mathrm{p}<0.01)$ re-mating interval $x$ season effect. Kit mortality was higher $(\mathrm{p}<0.05)$ during the rainy season in does under the intensive and semi-intensive re-mating systems. As postpartum re-mating interval increased, mortality decreased in both seasons.

\section{DISCUSSION}

One generally accepted advantage of early rebreeding is the willingness of the doe to accept the buck for mating. This was demonstrated in the result of this research as the mean re-mating intervals of 1.96 days and 13.89 days observed for does in the 19 days and 10-20 days groups respectively is on the lower side of the continum. Mating acceptance (\%) was also highest in the 1-9 days group and lowest in the 21-28 days group. Number of presentations before acceptance and the number of mating at acceptance demonstrated that the greatest willingness to mate was in the 1-9 days group. Decrease in willingness of does to accept the buck with increasing rebreeding interval observed in this research agrees with the findings of Partridge et al. (1984), Mendez et al. (1986), Cervera et al. (1993), Fortun-Lamothe and Bolet (1995) and Iyeghe-Erakpotobor et al. (2005). Since sexual receptivity was better during the dry season than rainy season in does re-mated under the intensive and semi-intensive systems, the probability that the small difference in the amplitude of photoperiodic changes may influence reproductive activity even under tropical conditions as reported by Mattaraia et al. (2005) cannot be ruled out.

The result on conception rate in this experiment agrees with the submission of Fortun-Lamothe and Bolet (1995) who reported that lactation decrease the percentage of females gestating by 33\%. Does under intensive and semi-intensive re-mating that were actively lactating in this experiment have $76.9 \%$ and $68.47 \%$ conception rates respectively. Nevertheless the result of conception rate in this experiment showed that fertility rate was higher in does re-mated 1-9 days postpartum than those re-mated 10-20 days postpartum. This is contrary to earlier research report that observed lower fertility rate when females were re-mated 1 day after parturition (Colin et al., 1980, Fraga et al., 1989). The negative effect of reduced re-mating interval on conception rate may therefore probably not be related to the uterine involution process as reported by Foxcroft and Hasnain (1973a) since does re-mated 10-20 days after parturition with better uterine involution had a lower conception rate than those re-mated intensively (1-9 days postpartum). The findings of this research 
agrees with the observations of Mendez et al. (1986) who reported that conception rate was generally higher in does re-mated 25 days vs. 1 day or 9 days re-mated rabbits. Reduction in pregnancy rate in does rebred early (1-9 days and 10-20 days postpartum) was observed to be due to either embryonic resorption and/or abortion. This agrees with the increase in embryonic loss reported by Foxcroft and Hasnain (1973b) and Mendez et al. (1986) as being responsible for reduced reproductive efficiency in does re-mated early postpartum.

Overall, the result of this experiment demonstrated that reducing the re-mating interval postpartum in the doe rabbit did not result in a linear increase or decrease in pregnancy rate. While pregnancy rate was highest in does under extensive (21-28 days postpartum) re-mating (93.75\%), it was lowest in does under semi-intensive (10-20 days postpartum) re-mating (52.63\%) and intermediate in does under intensive (1-9 days postpartum) re-mating (57.69\%). The plausible explanation for this response has to do with the physiology of the animals. Does rebred 10-20 days after parturition are at about the peak of lactation at the time of re-mating and therefore has the enormous responsibility of partitioning nutrient for high milk yield, embryonic survival and maintenance. Since nutrient demand for lactation is greater than pregnancy, (Awojobi et al., 2004), implantation and embryonic survival will likely suffer hence the observed embryonic resorption. Does re-mated 1-9 days postpartum were at the onset of milk production at the time of remating, the amount of nutrient partitioned to milk yield should therefore be lower than that of does re-mated 10-20 days postpartum, hence the higher conception rate. However, as milk production reaches its peak, embryonic resorption and even abortion becomes inevitable. Does re-mated 21-28 days postpartum were already experiencing decline in milk production, the kits were already nibbling at the feed and so they were likely to be partitioning the lowest amount of nutrient to milk production compared to the other two groups. So implantation and establishment of pregnancy was with less difficulty. Since weaning was at 28 days, all nutrient intakes thereafter were partitioned between preg-nancy and body maintenance. Caloric shortage has been reported to negatively affect fertility (Brecchia et al., 2005). Similarly, according to Fortun-Lamothe (1998) when females are simultaneously gestating and lactating, there is competition between the gravid uterus and mammary gland for the partitioning of nutrient and this takes place to the detriment of foetal growth.

The results of gestation length observed in this experiment fall within the normal range of 29-33 reported by MAFF (1973). Reducing the re-mating time postpartum has not been reported to have any significant effect on gestation length. However, the result of this experiment showed that gestation length was significantly $(p<0.05)$ shorter in does under semi-intensive remating (10-20 days postpartum). No immediate explanation could be adduced for these occurrences. Though not significant ( $p>0.05)$ gestation length was slightly longer in the dry season than rainy season. Abdulmalik (1994) had reported that gestation length of NZW does for the humid zone of Nigeria was lower than those of the savannah zone. This was reportedly due to variation in temperature and relative humidity of the two zones. While this report tends to agree with and also explain the present findings, it was also observed that the gestation length is best explained by the litter size and weight at birth.

Litter size at birth was not significantly ( $>0.05$ ) affected by postpartum re-mating interval and this agree with the finding of Partridge et al. (1984), Fraga et al. (1989), Dim and Abdullahi (1990) and IyegheErakpotobor et al. (2005). Stillbirths in this experiment were not significantly affected 
by postpartum re-mating interval and this agrees with the finding of Partridge et al. (1984) and Iyeghe-Erakpotobor et al. (2005).

Litter weight at birth followed the same trend as reported by Iyeghe-Erakpotobor et al. (2005) and agrees with the findings of Partridge et al. (1984) who reported that kit birth weight appeared to be unaffected by reducing the re-mating time after parturition. However, average kit birth weight increased with increasing postpartum re-mating interval. This is in line with the research findings of Fortune-Lamothe (1995) that body composition of kits at birth is affected by the superimposition of lactation and gestation. Litter weight at birth (total/alive) was significantly $(p<0.05)$ higher in the rainy than dry season. Iyeghe-Erakpotobor et al. (2001) also reported higher litter birth weight for kits kindled in the cool-wet season than other seasons. This the researchers attributed to higher feed intake as a result of lower daily temperatures, both of which were also observed in this research.

Litter size and weight at 21 and 28 days postpartum were not affected by postpartum re-mating interval. This agrees with the reports of Partridge et al. (1984) that 21 and 28 days litter weights all appeared to be unaffected by reducing the re-mating interval after parturition. Similarly, it agrees with the observations of IyegheErakpotobor et al. (2005) who reported a non-significant difference in weekly litter weight until 28 days at weaning in does rebred 14, 21 and 28 days postpartum. Reduced re-mating interval after parturition had no significant effect on litter size just as reported by Martin and Donal (1976), Partridge et al. (1984), Fraga et al. (1989) and Dim and Abdullahi (1990). Suffice it to say that though not significant, increasing the re-mating time after parturition was associated with increasing litter size as reported by Collin et al. (1980), Surdeau et al. (1980), Perrier et al. (1982). This is contrary to the report of Iyeghe-Erakpotobor et al. (2005) that does mated 14 days postpartum have more kits alive at 7 days up to 28 days postpartum than those rebred at 21 and 28 days postpartum. However, their research findings were equally not significantly different. The main effect of experimental re-mating showed that litter weight at 21 days was heaviest in does mated 1-9 days postpartum whereas the heaviest litter at 28 days was that of does re-mated 21-28 days postpartum. This development can be explained by the apparent reduction in milk production towards the end of lactation in does rebred early (Colin et al., 1980; Surdeau et al., 1980). Though there is a slight decrease in total milk production (Fraga et al., 1989) when does are re-mated early, this is of no practical importance because towards the end of lactation milk of does rebred early has higher concentration of protein and energy than those of non-pregnant does (Partridge et al., 1984). Hence the nonsignificant difference in litter weights observed in this study.

Partridge et al. (1984) reported no significant effect of postpartum re-mating on kits mortality. According to them, the least mortality (30\%) was observed in does rebred 1 day postpartum as opposed to $42 \%, 43 \%$ and $47 \%$ for does rebred 7,14 and 21 days postpartum respectively. Similarly Iyeghe-Erakpotobor et al. (2005) reported higher mortality for the 21 and 28 days postpartum rebred does compared to does rebred 14 days postpartum. However, in this experiment kit mortality decreased with increasing postpartum re-mating interval and values were significantly different. The findings of this experiment agree with that reported by Mendez et al. (1986). While most postnatal deaths across all treatments in this experiment was observed in the first week as also reported by Partridge et al. (1984), there was higher kit mortality at 2-4 weeks postpartum in does rebreed at 1-9 and 10-20 days postpartum on account of their reduction in willingness to nurse.

Kit mortality was generally higher in the 
rainy season than dry season. A higher number of kits died due to chilling during the rainy season. Chilling has been reported as a major cause of mortality in kits particularly in the first week of life (Partridge et al., 1984). The greatest incidence of kit mortality in does rebred 1-9 and 10-20 days postpartum occurred in the rainy season. Kit survival index at 21 days postpartum was lower in does rebred intensively and semi-intensively than those rebred extensively. Fraga et al. (1989) reported a lower survival index for does rebreed intensively (1 day postpartum) than does rebred semi-intensively ( 9 days postpartum) though values were not significantly different. However, survival index in this experiment was higher in does rebred intensively (1-9 days post-partum) than the ones rebred semi-intensively (10-20 days postpartum). The difference in result may be interpreted to be due to the difference in the specification of time period covered by the definition of intensive and semiintensive in this experiment. Nevertheless the report of Fraga et al. (1989) suggests that survival index will increase with

\section{BIBLIOGRAPHY}

A.O.A.C. 1995 . Official methods of analysis. $15^{\text {th }}$ ed. Association of Official Analytical Chemists. Washington. D.C.

Abdulmalik, M.E. 1994. Research on rabbit production in Nigeria: the NAPRI experience. Paper presented at the FACu National Workshop on Recent Advances in Agricultural Technology in Nigeria. $10-15^{\text {th }}$ October. Sheda. Abuja. pp. 37-42.

Awojobi, H.A., Odutayo, O.O. and Awojobi, E.A. 2005. Knowledge of reproduction management practices among rabbit farmers. Afr. J. Livestock Extension., 4: 78-83.

Awojobi, H.A., Opiah, G.O. and Sotuminu, G. 2004. The effect of physiological status on nutrient digestibility and some blood parameters of the New Zealand White doe rabbit. J. Agric. Forest. Social Sci., 2: 95-103. increasing days to mating postpartum and this was also true for this experiment except for the does rebred 10-20 days postpartum. The influence of season on survival index followed the same pattern as for kit mortality, and can obviously be explained along the same line of thought.

\section{CONCLUSIONS}

Fertility, fecundity and prolificacy potentials of the domestic rabbit were not significantly affected by postpartum remating interval under tropical climatic conditions.

Overall reproduction rate is comparable in does rebred intensively and extensively while does re-mated semi-intensively appears to have greater difficulty.

Pre-weaning re-mating in the domestic rabbit has peculiar problems for each of the mating systems: for does under extensive re-mating, it is willingness to mate, for does under intensive re-mating it is sustenance of pregnancy while does under semiintensive re-mating have these two problems combined.

Brecchia, G., Bonanno, A., Galeati, G., Federici, C., Maranesi, M., Gobbetti, A., Zerani, M. and Boiti, C. 2005. Hormonal and metabolic adaptation to fasting: effects on hypothalamic pituitaryovarian axis and reproductive performance of rabbit does. Domest. Anim. Endocrin., 31: 10522.

Castellini, B., Dal Bosco, A. and Mugnai, C. 2003. Comparison of different reproduction protocols for rabbit does: effect of litter size and mating interval. Livest. Prod. Sci., 60: 229-241.

Cervera, C.J., Fernândez-Carmona, J., Viudes, P. and Blas, E. 1993. Effect of remating interval and diet on the performance of female rabbits and their litters. Anim. Prod. 56: 399-405.

Cheeke, P.R. 1986. Potential of rabbit production in tropical and sub-tropical agricultural system. J. Anim. Sci., 63: 1581-1586. 
Colin, M., Rouillere, H., Simmonet, J. and Lucas, Y. 1980. Etude 'duene unite de grans - parentanx dams un elevage de lapin hybrids, premier resultants. Proceedings of the $2^{\text {nd }}$ Congress of the World Rabbit Science Association. BarceIona. Spain. 1: 274-283.

Dim, N.I. and Abdullai, A.H. 1990. Time of mating and rebreeding interval: effect on reproduction in rabbits. Proceedings of the $15^{\text {th }}$ Annual Conf. Nig. Olabisi Onabanjo University. Ago-Iwoye. Nigeria. Soc. for Anim. Prod. pp. 61-62.

Fortun-Lamothe, L. and Bolet, G. 1995. Les effets de la lactation sur le performance de reproductive chez la lapine. INRA. Prod. Anim., 8: 49-56.

Foxcroft, G.R and Hasnain, H. 1973a. Effects of suckling and time to mating after parturition on reproduction in the domestic rabbit. J. Reprod. Fertil., 33: 367-377.

Foxcroft, G.R. and Hasnain, H. 1973b. Embryonic mortality in post-parturient domestic rabbit. J. Reprod. Fertil., 33: 315-318.

Fraga, M.J., Lorente, M., Carabaño, R.M. and Blas, J.C. 1989. Effects of diet and of remating interval on milk production and milk composition of the doe rabbit. Anim. Prod., 48: 459-466.

lyeghe-Erakpotobor, G.T., Balogun, R.O., Abdul Malik, M.E. and Adeyinka, I.A. 2001. Influence of breed and environmental factor on litter parameters of rabbits raised in a semi-humid environment. Nig. J. Anim. Prod., 28: 14-19.

Iyeghe-Erakpotobor, G.T., Oyedipe, E.O, Eduvie, L.O. and Ogwu, D. 2005. Effect of rebreeding interval on reproductive performance and body weight changes of does during pregnancy. Nig. J. Anim Prod., 32: 142-152.

MAFF. 1973. Commercial RabbitProduction. Bulletin 50. Ministry of Agriculture Fisheries and Food. London.
Mattaraia, V.G.M., Bianospino, E., Fernandes, S., Vasconcelos, J.L.M. and Moura, A.S.A.M.T. 2005. Reproductive responses of rabbit does to a supplemental lighting programme. Livest. Prod. Sci., 98: 175-183.

Martin, M.M.S and Donal, R. 1976. Comparaison d'un rythme de reproduction intensif et d'un rythme semi-intensif chez la lapine. Premier Congrës International Cunicole. Dijon. France. $75 \mathrm{pp}$.

Mendez, J., De Blas, J.C. and Fraga, M.J. 1986. The effect of diet and remating interval after parturition on the reproductive performance of the commercial doe rabbit. J. Anim. Sci., 62: 1624-1634.

Onakomaiya, S.O., Oyesiku, K.A. and Jegede, S.J. 1992. Ogun State in maps. $1^{\text {st }}$ ed. Rex Charles Publications. Ibadan.

Parigi-Bini, R., Xiccato, G. and Gnetto, M. 1989. Influenza dell'intervallo parto-accopiamento sulle prestazioni riproduttive delle coniglie fattrici. Riv. Coniglicolt., 26: 51-57.

Partridge, G.G., Allan, J.J., Findlay, M. and Corrigall, W. 1984. The effects of reducing the remating interval after parturition on the reproductive performance of the commercial doe rabbit. Anim Prod., 39: 465-472.

Perrier, G., Surdeau, P., Dib, B. and Plassier, J.L. 1982. Ėtude comparée de deux rythmes de reproduction chez la lapine. Troisiémes Journées de la Recherche Cunicole. París. Francia. 3 pp. SAS Institute. 1999. SAS/STAT Users guide. Version 6.11. $5^{\text {th }}$ ed. Statistical Analysis System Institute Inc. Cary. N.C.

Surdeau, P., Matheron, G. and Perrier G. 1980. Étude compare de deux rythmes de reproduction chez le lapin de chair. Proceedings of the $2^{\text {nd }}$ Congress of the World Rabbit Science Association. Barcelona. Spain. 1: 313-321.

Archivos de zootecnia vol. 60, núm. 231, p. 512. 